\title{
Efficient and ultra-clean use of biogas in the fuel cell - the DFC experience
}

\author{
Mohammad Farooque*, Anthony Leo ${ }^{*}$, Anthony Rauseo and Jin-Yun Wang
}

\begin{abstract}
FuelCell Energy, Inc. (FCE) in Danbury, CT, currently offers three types of stationary fuel cell power plants: the DFC300, DFC1500, and DFC3000, rated 300, 1,400, and 2,800 kW, respectively, to operate on methane-rich fuels including renewable biogas. These products use the Direct FuelCell ${ }^{\oplus}\left(\mathrm{DFC}{ }^{\oplus}\right)$, which has the distinctive ability to generate electricity directly from a hydrocarbon fuel by reforming it inside the fuel cell and supplying hydrogen for fuel cell reactions. Biogas, which is available from distributed sources, contains $50 \%$ to $70 \%$ methane depending on the source and is an exceptionally desired fuel for DFC power plants. FCE has placed many biogas units ranging from $250 \mathrm{~kW}$ to $2.8 \mathrm{MW}$ around the world, achieving an electricity conversion efficiency of $45 \%$ to $49 \%$ (LHV). A unique feature of the DFC is that its performance is not impacted by biofuels diluted with $\mathrm{CO}_{2}(20 \%$ to $50 \%$ ). In fact, the DFC plants operating on biogas are consistently showing a higher fuel cell conversion efficiency (approximately $0.5 \%$ on a normalized basis) compared to pipeline natural gas plants. This is an advantage as removing $\mathrm{CO}_{2}$ from biogas (as is the case with the 'directed biogas') is energy intensive and adds cost. The existing DFC biogas applications focused on wastewater treatment, food processing, and brewery industries where the contaminants are primarily sulfur and siloxanes. FCE has used operational experience with these plants to improve gas supply reliability, understanding of the biogas contaminants, and improvement of removal process effectiveness.
\end{abstract}

Keywords: Direct FuelCellø; Biogas; Fuel cell; Biogas contaminants; Combined heat and power; Carbonate fuel cell

\section{Review}

\section{Background}

FuelCell Energy, Inc. (FCE) in Danbury, CT, is an integrated fuel cell company which develops, manufactures, sells, installs, and services high-temperature fuel cell power plants. FCE currently offers three commercial products: the DFC300, DFC1500, and DFC3000, rated $300,1,400$, and $2,800 \mathrm{~kW}$, respectively, to operate on methane-rich fuels including biogas. Currently, over 80 $\mathrm{DFC}^{\bullet}$ plants are operating at more than 50 sites having generated more than 2.8 billion kilowatt hours of ultraclean, efficient, and reliable power for customers around the world. The power-producing block of these products is the FCE-developed Direct FuelCell (DFC $)$. The DFC has the special ability to generate electricity directly from a hydrocarbon fuel by reforming it inside the fuel cell and supplying hydrogen for fuel cell reactions. This 'one-step' internal-reforming fuel-cell process results in

\footnotetext{
* Correspondence: mfarooque@fce.com; tleo@fce.com

FuelCell Energy, Inc., 3 Great Pasture Road, Danbury, CT 06813, USA
}

a simpler, efficient, and cost-effective energy conversion system resulting in unique benefits:

- Virtually no pollutant emissions - Easy to site in congested/urban areas

- Highest electrical efficiency vs. competing generation alternatives

- Generates more power output per unit of fuel input with $47 \%$ and higher electrical efficiency

- Up to $90 \%$ total efficiency when using combined heat and power $(\mathrm{CHP})$

- Fuel flexible

- Operates on cleaned abundant natural gas and/or renewable biogas

These unique features are driving the market growth (over $300 \mathrm{MW}$ of installed and backlog capacity spreading over nine countries) in two segments of the power generation market: (1) on-site power generation (typical applications shown in Figure 1) and (2) utility grid support (an example shown in Figure 2). 


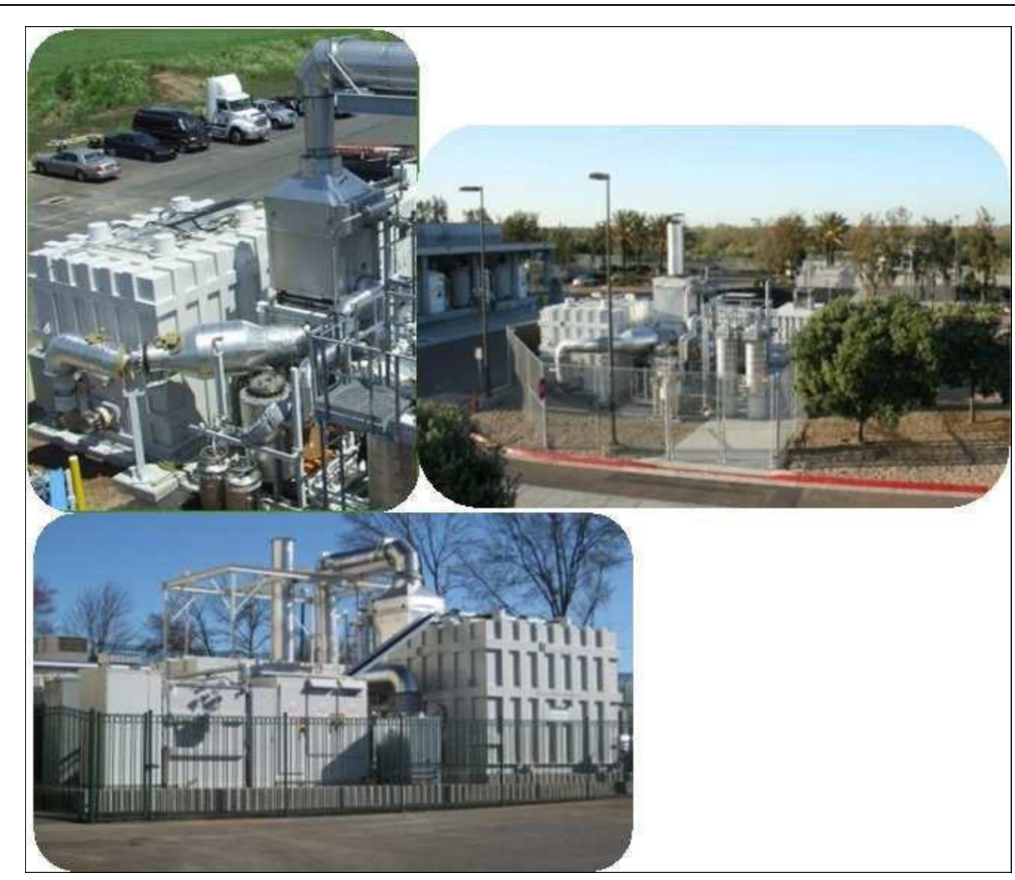

Figure 1 On-site fuel cell power plants. CHP applications at a university, a commercial bakery, and a municipal hydrogen pump station.

DFC fuel cells also have a relatively high exhaust temperature $\left(370^{\circ} \mathrm{C}\right)$, which enables a wide variety of waste heat uses in combined heat and power applications, including steam generation, hot water production, and absorption chilling. In addition to reduced $\mathrm{CO}_{2}$ emissions, DFC emissions of harmful pollutants such as nitrogen oxides $\left(\mathrm{NO}_{x}\right)$, sulfur oxides $\left(\mathrm{SO}_{x}\right)$, and particulate matter are negligible and orders of magnitude lower than conventional combustion-based power plants.

The biogas produced from biomass is a carbon-neutral renewable fuel. This fuel is usually flared or released into the environment as a waste gas. An energy generation technology that can efficiently produce electricity and heat with low emissions when operated in a distributed generation mode is most desired for the biogas applications. The DFC was developed to provide green electricity and heat from methane in a distributed generation mode and uniquely qualifies for this application. FCE has pursued biogas applications for the DFC since the start of commercialization of DFC power plants in 2003 and has used the operational experience with these early plants to improve the design (gas supply reliability, understanding of the contaminants, and control). FCE practice on biogas, knowledge of the contaminants, and discussion of the system design based on the initial project experience was discussed in an earlier paper [1] and an update is provided in this article.

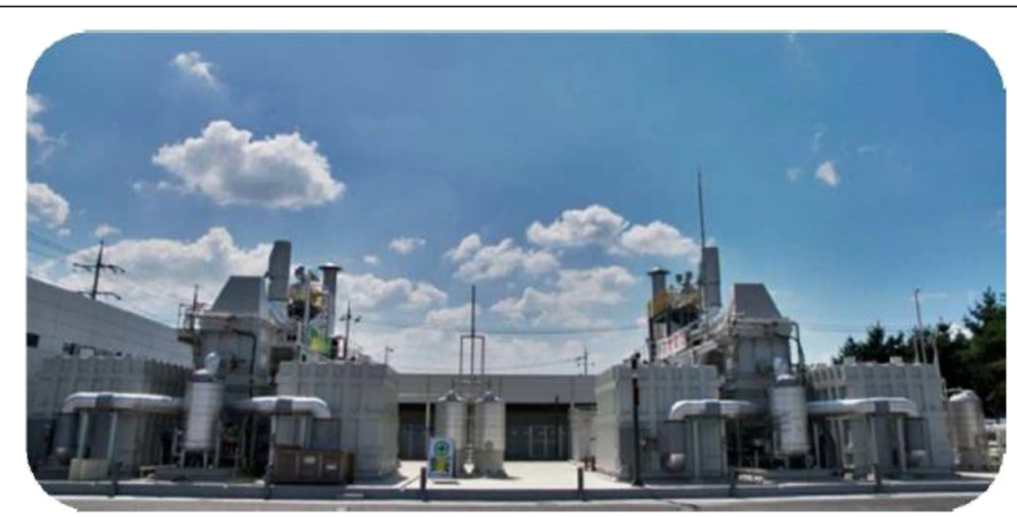

Figure 2 Fuel cell park: supporting the site electric grid. 


\section{The DFC biogas advantage}

The direct carbonate fuel cells were initially developed for natural gas fuels as a robust natural gas distribution network exists in the markets targeted by FuelCell Energy. The biogas produced by anaerobic digestion in wastewater treatment, food processing industry, and decomposition of wastes in landfills contains predominantly methane and $\mathrm{CO}_{2}$. It can be used in a DFC designed for the natural gas to produce ultra-green electricity and usable heat. Also, the byproduct heat of the DFC using the biogas is a good match for heat required by the anaerobic digestion process that produces the gas. The high $\mathrm{CO}_{2}$ content in the biogas negatively impact the performance of the anodic reaction of all fuel cell technologies including the carbonate fuel cell. However, a unique feature of the DFC is that its performance loss at the anode due to fuel dilution is compensated by a performance gain at the cathode due to higher reactant $\left(\mathrm{CO}_{2}\right)$ concentration at the cathode. In fact, the DFC open circuit potential in biogas systems is slightly higher (approximately $4 \mathrm{mV}$ ) than the natural gas system. The stack performances of several DFC plants operating on the biogas and the pipeline natural gas at different customer sites are compared in Figure 3. Although natural gas and biogas compositions are different at all sites, a slight biogas performance advantage over natural gas is clearly evident at each site. On average, the biogas plants operate at approximately $0.5 \%$ higher fuel cell conversion efficiency.

The digester gas output volume as well as the chemical fuel value of the gas can vary depending on the digestion system variables. Additionally, the digester gas is not available for power production during maintenance operation. To ensure constant power production with digester gas, FCE has developed a fuel-flexible DFC design, where the power plant automatically blends in

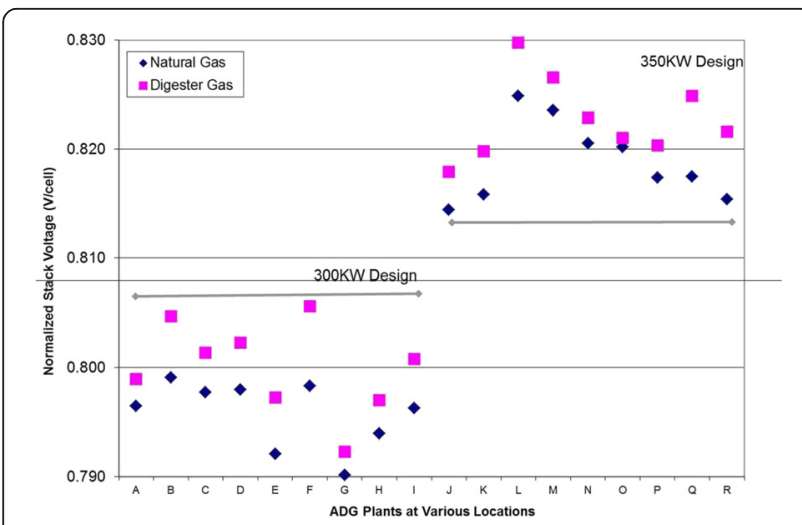

Figure 3 DFC performance comparison. ADG vs. natural gas (at different customer sites and using latest generation 350-kW stack along with earlier generation 300-kW stack). On average, approximately 4-mV higher cell voltage is seen with the digester gas. natural gas to adjust for the digester gas shortfall. An example of this fuel-flexible operation is shown in Figure 4. Fuel flow switched automatically from digester gas to natural gas as the digester switched off-line and later the plant switched to digester gas from natural gas, as the digester was brought on stream.

In the direct fuel cell, approximately two thirds of the fuel cell reaction byproduct heat is used up by the reforming reaction and most of the remaining one-third heat is removed by the process gas as sensible heat. The biogas system process streams have higher heat removal capacity than natural gas systems due to a greater amount of carbon dioxide content. Because of the higher heat removal capacity (due to the higher heat capacity of the process streams) and improved cell performance advantages, DFC stacks operate at a lower temperature, approximately $15^{\circ} \mathrm{C}$, than the natural gas system at the same output power.

\section{Biogas cleanup for DFC}

Biogas containing methane is produced from anaerobic digestion of organic materials from various sources such as municipal wastewater, food/beverage processing waste, waste solids from ethanol production, and farm animal waste. The biogas produced from these sources primarily contains methane (generally $50 \%$ to $70 \%$ ), carbon dioxide, water vapor, and traces of other gases. It also potentially contains contaminants such as oxygen, sulfur, siloxanes, halogens and, in landfill applications, heavy metals. Table 1 provides a preview of gas compositions and potential contaminants from different potential sources of biogas and natural gas. These gases are required to be cleaned for most of the energy recovery applications. Siloxanes are cleaned to about 1 ppm to prevent $\mathrm{SiO}_{2}$ deposition on pistons, heat exchangers, or catalyst for emission control, and sulfur compounds are cleaned to several ppm for most potential applications [2]. This is to prevent $\mathrm{SO}_{2}$ release to air as well as to avoid corrosion. A deeper cleaning of sulfur compounds is required for the DFC application. A plus of DFC technology is that the gas cleanup is less intensive than required for pipeline quality gas, termed 'directed' biogas. Directed biogas must have $\mathrm{CO}_{2}$ removed, which is energy intensive and adds additional cleanup costs.

The municipal and non-municipal anaerobic wastewater treatment plants (WWTPs) represent a significant source of biogas in the USA. The output gas from the WWTPs employing a sulfide control process contains $<300 \mathrm{ppm}$ of $\mathrm{H}_{2} \mathrm{~S} . \mathrm{H}_{2} \mathrm{~S}$ content in an untreated WWTP biogas is in excess of 2,000 ppm by volume [3]. Usually, control technologies are employed to contain it to safe levels to meet the emission criteria for energy recovery use and emission to the environment. A comparison of the potential bulk 


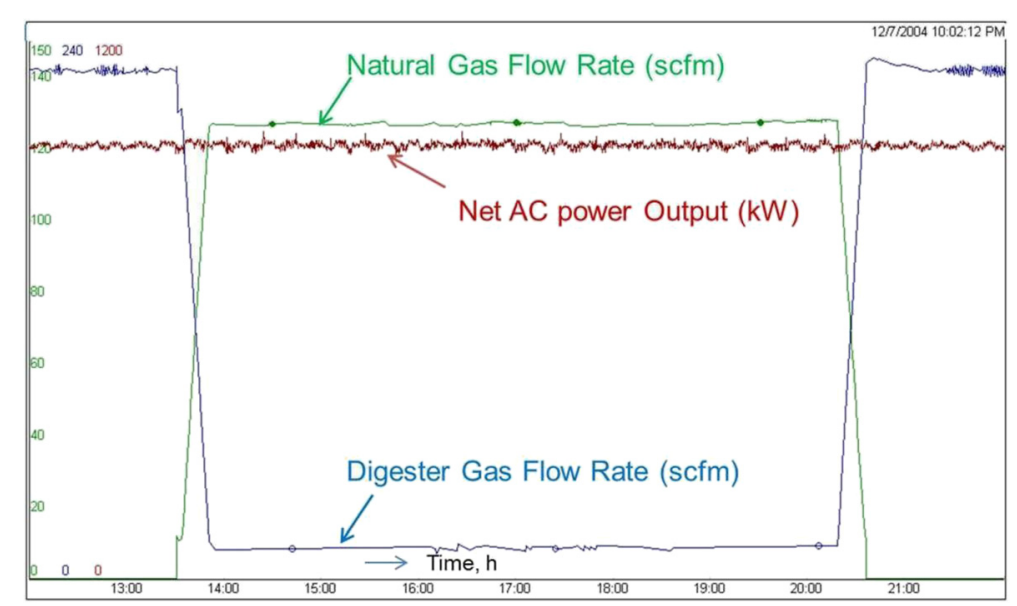

Figure 4 Fuel flexible operation example. Fuel flow switched from digester gas and back to digester gas autimatically not affecting the output.

sulfur control technologies is discussed by Soroushian et al. [4], and the power production potential in the USA from the biogases produced from the WWTPs is discussed by Leo et al. [5].

The impurity levels in ADG, even with sulfur control technology, are significantly higher than those in natural gas. The type and level of contaminants are dependent on the gas source. An auxiliary fuel cleanup system is used for cleaning the biogas before the introduction to the fuel cell. The design of the contaminant removal system requires a detailed knowledge of the contaminant species, their levels, and potential variation with time. Usually, a dedicated auxiliary biogas treatment system as illustrated in Figure 5 (the biogas-specific cleanup is shown with the natural gas power plant block flow diagram in dotted lines) is used to control the contaminant levels in biogas for use in a fuel cell. The contaminant treatment process is carried out in several steps. In the first step, most of the sulfides are removed by treating with iron oxide under a controlled environment. The controlling parameters for this process are space velocity of the gas, residual oxygen content, relative humidity, condensate $\mathrm{pH}$, etc. The iron oxide bed is not effective in removing organic sulfides. After moisture conditioning, a cleanup bed, usually an activated carbon bed, is employed for siloxanes escaping from the iron oxide treatment [6]. Finally, trace organic sulfur compounds present in the biogas leaving the dehumidifier is removed using a sorbent for high-temperature fuel cell use. Applications where organic sulfur content is low, and only one single bed is available, are employed to combine siloxanes and organic sulfur removal functions. A De-Ox catalyst bed incorporated in front of the pre-reforming catalyst bed is used to remove residual oxygen in the biogas.

Special attention is also required for performance monitoring of the cleanup system to ensure reliability of the gas cleanup system. The operating cost of the sulfur polishing system can be high due to frequent monitoring

Table 1 Typical fuel composition (natural gas vs. biogases)

\begin{tabular}{|c|c|c|c|c|c|}
\hline \multirow[t]{2}{*}{ Composition } & \multirow[t]{2}{*}{ Natural gas } & \multicolumn{4}{|l|}{ Biogases } \\
\hline & & Wastewater & Food waste & Animal waste & Landfill \\
\hline Methane (vol.\%) & 80 to 100 & Approximately 50 to 65 & Approximately 50 to 70 & 45 to 60 & 40 to 55 \\
\hline Carbon dioxide (vol.\%) & 0 to 3 & 35 to 45 & 25 to 45 & 35 to 50 & 35 to 50 \\
\hline Nitrogen (vol.\%) & 0 to 3 & 0 to 5 & 0 to 5 & 0 to 5 & 0 to 20 \\
\hline Oxygen (vol.\%) & 0 to 0.2 & 0 to 1 & 0 to 1 & 0 to 1 & 0.5 to 4 \\
\hline Higher hydrocarbons (vol.\%) & 0 to 15 & Negligible & Negligible & 0 to 1 & 0 to 1 \\
\hline \multicolumn{6}{|l|}{ Impurities (ppm) } \\
\hline $\mathrm{H}_{2} \mathrm{~S}$ & 0 to 0.1 & 0 to 3,000 & 0 to 10,000 & 0 to 3,000 & 0 to 2,000 \\
\hline Non- $\mathrm{H}_{2} \mathrm{~S}$ sulfur & 0 to 10 & 0 to 1 & 0 to 1,000 & 0 to 30 & 0 to 50 \\
\hline Halogens & $<0.1$ & $<0.2$ & $<0.2$ & $<0.2$ & 0 to 100 \\
\hline
\end{tabular}

Biogas cleanup challenges include light sulfur compounds, siloxane, and halogens (particularly in the presence of moisture). 


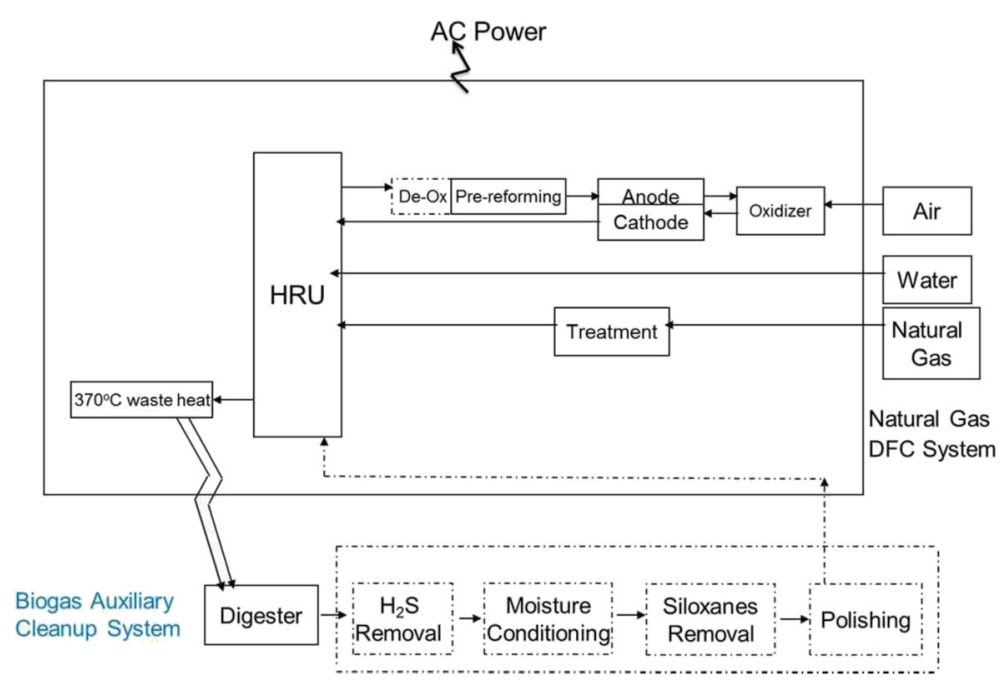

Figure 5 Schematic showing biogas adaptations to natural gas DFC. An auxiliary cleanup system is needed to control sulfur and siloxane compounds.

requirements and low sulfur intake capacity of the commercial sulfur polishing agents. FCE has developed two separate equipment solutions for inexpensive online sulfur monitoring and breakthrough detection. Both of these equipment solutions are currently under evaluation with DFC power plants operating on biogas.

DFC has much more stringent requirements on sulfur $(<30 \mathrm{ppb})$ than internal combustion (IC) engines. The second bed is designed to remove the large molecules of siloxanes to $1 \mathrm{ppm}$ level and has very low capacity for light sulfur compounds, such as DMS, $\mathrm{CS}_{2}$, and COS, especially in the presence of moisture in ADG ( $\geq 10 \% \mathrm{RH})$. There is no commercially available technology to remove these small amount of organic sulfur compounds to $<30 \mathrm{ppb}$ level (as desired for the fuel cell application) efficiently.
The development of advanced materials that could be employed as polishing media to supplement the weakness of the currently available polishing medium would help to lower the biogas cleanup costs for fuel cells. It is encouraging that the availability of such a novel sorbent system has been disclosed [7].

\section{Biogas DFC experiences}

FCE has placed over 25 biogas units ranging from $250 \mathrm{~kW}$ to $2.8 \mathrm{MW}$ around the world, achieving an electricity conversion efficiency of $45 \%$ to $49 \%$ (LHV) without accounting for power consumption by the biogas auxiliary cleanup process. A vast majority of the plants are operating on biogas produced by the wastewater treatment plants; a few plants have operated on biogas

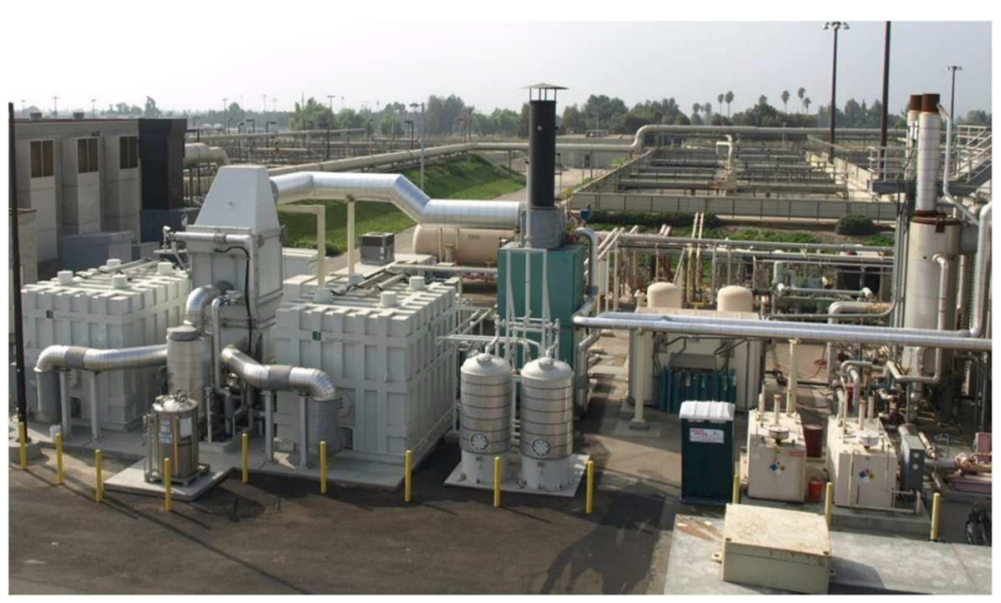

Figure 6 Biogas DFC 2.8-MW plant in California, USA: world's largest fuel cell plant on biogas. 


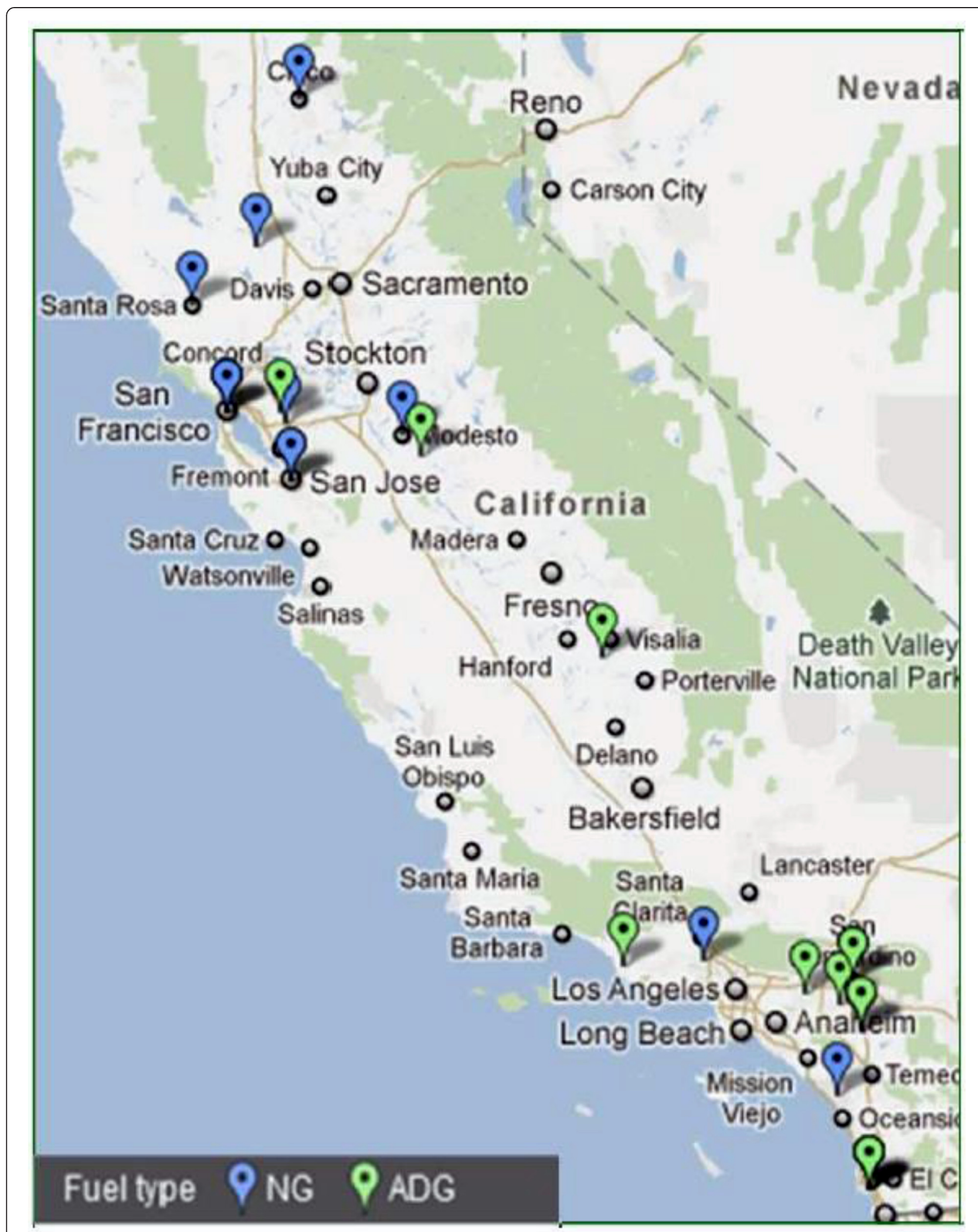

Figure 7 Natural gas and biogas DFC plants in California. More than half are biogas plants (approximately 14 MW). 
produced during beer production process. Two sub-MW plants at Oxnard, CA, are operating on biogas produced by anaerobic digestion of onion juice. The Gills Onions Oxnard plant has won several environmental and economic leadership awards (go to www.gillsonions.com/ validation; it provides details of awards and recognitions received). Although biogas from onion juice does not contain siloxanes, it does have very high level of sulfur compounds with total sulfur at about $10,000 \mathrm{ppm}$ or approximately $1 \%$ by volume in the biogas. It is challenging to completely digest such high levels of sulfur compounds to $\mathrm{H}_{2} \mathrm{~S}$ with a limited residence time in the digester. As a result, there is a considerable amount of organic sulfur, mainly propanyl mercaptan, in the raw biogas from the digester. As iron oxide media has almost no capacity for adsorption of these two organic sulfurs, multistages of organic sulfur removal beds are used with lead/lag option to get the maximum efficacy of the media. FCE and customers have been working together diligently and very effective, and an efficient sulfur removal has been obtained for the last several years. Two plants in California, USA, are operating on directed biogas which has similar gas composition as the natural gas.

Potential issues encountered for biogas applications primarily relate to the steadiness of fuel gas supply (gas supply and composition variations). The volume of flow would occasionally drop below the level needed for full-load operation. When this occurred, the fuel pressure would become too low and the unit would trip off-line. Also, the fuel content in the gas can vary diurnally as well as seasonally. FCE experience with early power plants has identified another important point relating to the digester gas availability. In realworld applications, digester plant operators do not consider maintaining a steady supply of ADG to be of high priority. Furthermore, it is a waste stream, which has little impact on their day-to-day operations. When the ADG supply is interrupted, which sometimes can be caused by maintenance activities or changes in sewage waste composition entering the plant, the fuel cell power plant needs to be able to respond.

The four DFC300 plants at the Sierra Nevada Brewery installation were used to develop the ADG and natural gas blended operation. The amount of digester gas available from the wastewater digester at the site was able to support approximately $25 \%$ of the 1MW total power generation capacity. A fuel blending feature was developed, which allows the power plants to use all of the available digester gas, and then blend in enough natural gas to make full power output. The fuel blending application developed for these plants helped to enhance the ability of the product in biogas applications with limited or varying fuel supply rates. The solution to solve the fuel supply issue is to install a back-up natural gas fuel line, which is relied upon to keep the fuel cell in operation with natural gas blending when ADG supply is short or operate on natural gas when the ADG supply is interrupted. Through a process of software logic development and actual experiments with the power plant, an automatic approach to switch from the primary fuel to a secondary fuel during full or part load was achieved. This capability proved extremely useful in all applications where the fuel supply and/or fuel value are not steady. Figure 4 (shown earlier) provides an example of automatic switchover from digester gas to natural gas, dual-fuel operation during transition, and back to digester gas based on digester availability while maintaining full power production during the entire period. This dual-fuel operation capability has now become a part of FCE's biogas plant design to mitigate biogas flow uncertainties. All biogas plants currently in operation have the dual-fuel operation capability.

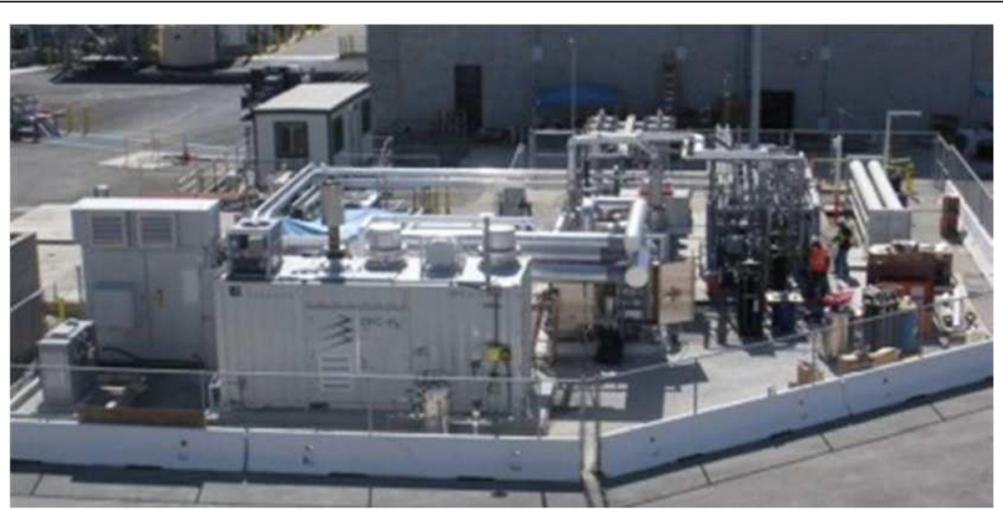

Figure 8 DFC 250-kW plant in demonstration operation in Orange County Sanitation Department Water Treatment Biogas Facility. Capable of providing electricity, pure hydrogen, and heat. 
Smooth operation of biogas pretreatment for fuel cells (for removal of sulfur compounds and siloxanes discussed previously) is an important component of the system for reliable operation. The operation of the early units was affected by the reliability of the pretreatment skids, which are supplied by the end user or a distributor. This has improved over time, as lessons learned from early units were incorporated into the design and maintenance of the newer systems.

The initial biogas DFC plants were of a sub-MW class. These early plants provided the 'test bed' to understand the concerns related to plant availability, gas cleanup design, and maintenance routines to develop improvements and to verify in field operation. Consequently, as plant availability and reliability improved, the customer trend has been towards larger (economically attractive) size plants. A photograph of the largest biogas DFC 2.8-MW plant in operation in California, USA, is shown in Figure 6.

FCE has over $15 \mathrm{MW}$ of power plants currently operating on renewable biogas with the majority of these renewable fuel power plants located in California (Figure 7) - more than half of FCE's California DFC installations are for biogas operation (approximately $14 \mathrm{MW}$ ). The California Self-Generation Incentive Program promotes the adoption of clean distributed generation and has facilitated the marketing of DFC power plants.

The DFC power plants are currently produced in low volumes, and as a result, the capital costs tend to be higher than the conventional distributed generation technologies. Due to its high efficiency and clean emissions, a variety of capital cost rebate programs are making the biofuel DFCs economical and competitive with natural gas internal combustion engines and micro-turbines [3], particularly in regions that require downstream emission cleanup of internal combustion power generation. Higher production volumes will also help to drive down costs.

\section{Advanced biogas DFC system}

FCE is also developing an advanced biogas DFC design for tri-generation applications (power, heat, as well as hydrogen) providing high efficiency, ultra-clean electricity, high-purity hydrogen for on-site use, and heat. The hydrogen produced can be used for fuel cell vehicle fueling and/or other industrial applications. A sub-MW plant incorporating this novel concept has been in demonstration (Figure 8) at Irvine (CA) in collaboration with Orange County Sanitation District, National Fuel Cell Center (Irvine, CA), Air Products, South Coast Air Quality Management District, and California Air Resources Board since late 2010.

The cost of power for a biogas plant depends on the cost of cleanup and local economics (incentives). In California with SGIP (Self-Generation Incentive Program), DFC cost of electricity (COE) is 9 to 11 cents per $\mathrm{kWh}$ for biogas plants. The DFC California projects produce power below the retail power cost, which is 10 to 12 cents per $\mathrm{kWh}$ in the state. Without the incentives, the cost of electricity will be approximately 2 cents per $\mathrm{kWh}$ higher. In a Tri-gen plant, the cost for hydrogen equipment is covered by another revenue stream (hydrogen sales, which are about the same value as power sales), so the value of DFC power would be in the same 9- to 11-cent range with hydrogen credit and without the SGIP incentive.

\section{Conclusions}

FuelCell Energy gained considerable experience with DFC power plant biogas applications, which have become an important market segment addressed by its products. The product enhancements from the initial projects have resulted in the development of features which address the specific needs of the biogas market: operate efficiently at full load despite the presence of the $\mathrm{CO}_{2}$ diluents, adjust to the changing fuel composition and quantity, and operate with minimal emissions and minimal operator intervention.

\section{Abbreviations}

ADG: anaerobic digester gas; CHP: combined heat and power; DFC: direct fuel cell; FCE: FuelCell Energy, Inc.; LHV: lower heating value; WWTP: wastewater treatment plant.

\section{Competing interests}

The authors work for FuelCell Energy, Inc. The company is engaged in the development of the carbonate DFC power plants as well as the solid distributed power generation applications on reformable fuels including the biogas. The subject of the present paper deals with commercial readiness of the DFC for biogas application.

\section{Authors' contributions}

MF directed the analysis of plant performance data and drafted the manuscript. J-YW provided input for biogas contaminant cleanup requirements for the direct fuel cell and selection of the appropriate cleanup systems. AR directed the biogas DFC power plant design and engineering. AL provided customer feedback and guidance for plant performance and reliability improvements and conducted the economic analysis. All authors read and approved the final manuscript.

\section{Acknowledgements}

The contributions of many engineers and technicians at FCE, partners, and vendors in the development of this unique green technology as well as the funding from several sponsors are acknowledged.

Received: 20 March 2014 Accepted: 12 March 2015

Published online: 16 April 2015

\section{References}

1. Farooque M, Daley J, Leo T, Pais C, Venkataraman R, Wang J (2011) Direct fuel cell experience on renewable biogas. ECS Trans 30(1):261-270

2. Wheless E, Pierce J Siloxanes in landfill gas and digester gas update. http:// www.scsengineers.com/Papers/Pierce_2004Siloxanes_update_paper.pdf

3. Lono-Batura M, Qi Y, Beecher N (2012) Biogas production and potential from U.S. wastewater treatment. BioCycle 53(12):46

4. Cherosky P, Li Y (2013) Hydrogen sulfide removal from biogas by bio-based iron sponge. Biosyst Eng 114(1):55-59

5. Soroushian F, Shang Y, Whitman E, Garza G, Zhang Z (2006) Development and application of biological $\mathrm{H}_{2} \mathrm{~S}$ scrubbers for treatment of digester gas. In: Proceedings of WEFTEC'06., pp 3541-3547 
6. Leo A, Pais C (2010) Biogas applications for molten carbonate fuel cells. In: Proceedings of the International Colloquium on Environmentally Preferred Advanced Power Generation, ICEEPAG2010-3486

7. Alptekin GO, Jayaraman A, Schaefer M, Dubovik M, Ware M (2013) Novel sorbents to clean up biogas for fuel cell CHP systems. 2013 Fuel Cell Seminar \& Exposition Extended Abstract, Columbus, $\mathrm{OH}$

Submit your manuscript to a SpringerOpen ${ }^{\odot}$ journal and benefit from:

- Convenient online submission

- Rigorous peer review

- Immediate publication on acceptance

- Open access: articles freely available online

- High visibility within the field

- Retaining the copyright to your article

Submit your next manuscript at $\boldsymbol{\nabla}$ springeropen.com 